УДК 378.04.091.33:316.77]:338.48

\title{
ВАДИМ СІДОРОВ
}

Харківський національний університет імені В.Н. Каразіна, Україна

\section{ДЕЯКІ МЕТОДИ ФОРМУВАННЯ КРОСКУЛЬТУРНОЇ КОМПЕТЕНТНОСТІ МАЙБУТНІХ ФАХІВЦІВ ГАЛУЗІ ТУРИЗМУ}

У статті схарактеризовано методи формування кроскультурної компетентності майбутніх фахівців галузі туризму, а саме: метод case-study, «мозковий штурм» (Brainstorming), модерація, метод SWOT-аналізу, метод «Культурна капсула країни», сторітеллінг (Storytelling), метод «Вавілон», метод World Café («Всесвітнє кафе»).

Ключові слова: кроскультурна компетентність, туризм, фахівець, кроскультурна підготовка, метод, групова робота

Постановка проблеми. Актуальність проблеми обумовлена необхідністю пошуків нових підходів до кроскультурної підготовки майбутніх фахівців галузі туризму, підготовки сучасних студентів до ефективного виконання професійних обов'язків працівника туристичної індустрії в іншокультурному середовищі. У цьому контексті модернізація змісту туристичної освіти у вітчизняних 3ВО посилюється в напрямі формування кроскультурної компетентності майбутніх фахівців галузі туризму, що робить їх активними учасниками взаємодії національних культур різних країн.

Аналіз останніх досліджень. Незважаючи на те, що існуючі теоретичні та практичні підходи до проблеми формування кроскультурної компетентності (Ж. Ахмад, Г. Дідук-Ступ'як, О.Дем'яненко, А. Науменко, О. Пальчикова, А.Солодка, О. Резунова, Р.Левітт, Г.Ферраро та ін.) внесли свій вагомий внесок в кроскультурну підготовку студентів, недостатньо було розглянуто питання методів формування кроскультурної компетентності майбутніх фахівців галузі туризму.

Мета статті: схарактеризувати суть методів навчання, які сприяють ефективному процесу формування кроскультурної компетентності майбутніх фахівців галузі туризму.

Виклад основного матеріалу. У процесі формування кроскультурної компетентності майбутніх фахівців галузі туризму можливим є застосування будь-яких методів навчання, відомих у сучасній педагогіці. Не викликає сумніву той факт, що ефективними будуть інтерактивні методи, які базуються на концепції М. Бахтіна. Основними положеннями цієї концепції є:

проблема «Я - Інший», яка конкретизується поняттями «Я - для - Себе», «Я - для - Іншого», «Інший - для Мене»;

діалогічність - активність того, хто пізнає, та активність того, хто відкривається;

пізнання і самовираження - уміння пізнати і уміння виразити себе;

взаємодія - взаємодія кругозору того, хто пізнає, з кругозором іншого суб'єкта пізнання;

вираження - роль елементів вираження (тіло не як мертва річ, обличчя, очі тощо), у ньому схрещуються i з'єднуються дві свідомості («Я та Іншого»), тут «Я» існує для «Іншого» і за допомогою «Іншого» (Бахтин, 1986; Скрипник, 2013). У своїй концепції дослідник пропагував основну ідею: існує особлива діалогічна сфера буття людини, і саме буття людини є найглибшим спілкуванням, тобто, бути - означає спілкуватися. Учений акцентує увагу на тому, що саме у діалозі відбувається взаємодія різних контекстів, культур, світоглядів, точок зору, експресивно-акцентних систем, соціальних «мов».

Нині у педагогіці існує значна кількість наукових праць, довідників, енциклопедій, присвячених інтерактивними методам навчання (О. Ворожейкіна, О. Пометун, М. Скрипник, А. Хуторськой та ін.). Кожен 3 викладачів може обрати з них будь-який, який вважатиме за потрібне у той чи інших момент освітнього процесу у залежності від мети, завдань, очікуваних результатів. Пропонуємо деякі з методів, які, на нашу думку, найбільш ефективно сприятимуть формуванню у майбутніх фахівців галузі туризму кроскультурної компетентності: метод case-study, мозковий штурм» (Brainstorming), модерація, метод SWOT-аналізу, метод «Культурна капсула країни», сторітеллінг (Storytelling), метод «Вавілон», метод World Café («Всесвітнє кафе»).

Метод case-study (Ш. Бобохужаєв, А. Долгоруков, С. Ковальова, І. Козіна, Н. Кононец, Е. Михайлова, Л. Покушалова, Ю.Сурмін, 3. Юлдашев). Його впровадження в освітній процес підготовки студентів спеціальності «Туризм» сприятиме не лише формуванню кроскультурної компетентності, але й динамічності, здатності діяти результативно в нестандартних ситуаціях, розвитку широкого спектру інформаційнопошукових і практично-професійних умінь та навичок, насамперед, аналітичних, комунікативних тощо (Кононец, 2016). Наведемо приклад кейсу.

Кейс «Позиціонування семи чудес України»

Позиціонування - це одна 3 основних маркетингових процедур, що дозволяє зіставити і оцінити (C) В. Сідоров, 2018 
конкуруючі товари, об'єкти, сегменти ринку і положення фірми, регіонів, країни порівняно з конкурентами, щоб забезпечити їм виграшне місце в перспективних сегментах ринку й у свідомості цільових груп туристів. При цьому привабливим для туристів об’єктів слід надати впізнаванні характеристики і розкручувати їх на ринку туризму. У деяких випадках окремі соціально-територіальні спільноти активізуються після проведення конкурсів. Фактично результати конкурсів відображають рівень регіональної ідентичності та активності територіальних спільнот різного рівня. Певну роль для країни, її регіонів може зіграти вибір семи чудес України і просування їх на світовому туристичному ринку.

Сім чудес світу - це творіння, які своєю технічною і художньою досконалістю викликали захоплення людей минулих століть. 3 узаконених енциклопедіями і довідниками семи чудес світу до сьогодні дожили тільки єгипетські піраміди. Тому за проектом, організованим організацією «New Open World Corporation» 3 ініціативи швейцарського мандрівника Бернара Вебера, було проведено пошук сучасних семи чудес світу. А 7 липня 2007 року в Лісабоні був оголошений їх список. Жоден з об'єктів України не потрапив до цього списку. Ідея пошуку нових чудес була підхоплена деякими країнами. Так, в Україні в травні 2007 р. стартувала акція «Сім чудес України». У регіонах були створені оргкомітети, які запропонували на всеукраїнський однойменний конкурс різні об'єкти. Близько тисячі об'єктів було відібрано. На наступному етапі експертна рада у складі культурологів, істориків, фахівців туристичного бізнесу (всього сто осіб) вибрали список спочатку з 100, а потім з 21 об’єкта для Інтернет-голосування, яке почалося 7 липня 2007 року. Кількість об'єктів, що входять в 100, сильно варіювала по регіонах України. Найкраще була представлена Київська область (разом 3 м. Київ) - 11 об’єктів, а мінімальна кількість об’єктів (1) була у Донецькій області. В Інтернет-голосуванні брало участь 77 тис. осіб.

31 листопада 2007 року в Україні стартувала акція семи природних чудес України з метою пропаганди унікального природного світу України та привернення уваги до об'єктів, які можуть стати цікавими не лише для українського, а й для закордонного туристичного товариства. Об’єкти для участі в конкурсі - геологічні об’єкти, озера, річки, природні масиви і т. д. Для цього було відібрано 100 природних об'єктів України, після чого експерти обрали 21 об’єкт. Далі за допомогою інтернет-голосування та з урахуванням думки експертів були визначені сім чудес України. Переможці акції були оголошено 26 серпня 2008 року. Ними стали: біосферний заповідник «Асканія-Нова» (Херсонська обл.); регіонально-ландшафтний парк «Гранітно-степове Побужжя» (Миколаївська обл.); Дністровський каньйон (Вінницька, Івано-Франківська, Тернопільська, Хмельницька обл.); мармурові печери в Криму; національний природний парк «Подільські Товтри» (Хмельницька обл.); озеро Світязь (Волинь); озеро Синевир (Закарпаття). Один з ініціаторів акції М. Томенко підкреслив, що серед семи чудес немає переможців. «Всі вони рівні, оскільки це природні чудеса України». Отже, загальнонаціональний конкурс з вибору семи чудес показав жителям країни і всьому світу туристичну привабливість і цінність історико-культурних шедеврів України, які залишилися від попередніх поколінь. Найяскравіші їх елементи можуть бути використані в якості туристичних брендів (Україна на світовому...,2016).

Завдання.

Знайти рейтинг претендентів, які брали участь в Інтернет-голосуванні.

Створити презентацію про 2-3 об’єкти з рейтингу претендентів.

Скласти власний кейс «Сім чудес Харківщини», організувати опитування серед студентів та жителів міста, підвести результати.

Організувати студентську конференцію «Сім чудес Харківщини», запросити студентів-іноземців для ознайомлення $з$ культурою та пам'ятками Харківщини, з'ясувати ставлення учасників до запропонованого списку семи чудес, обговорити.

Метод «Мозковий штурм» (Brainstorming) детально розкривається у працях таких науковців, як I. Дичківська, О. Радіонова, Л. Сидоренко, Г. Сиротенко, Г. Цехмістрова. Цей метод - це спільна одноразова робота групи експертів, спрямована на творчий пошук, як правило, нетрадиційних, креативних підходів до вирішення певної задачі, збір якомога більшої кількості ідей у результаті звільнення студентів від інерції мислення та стереотипів. Мозковий штурм забезпечує комунікативну спрямованість освітнього процесу, сприяє реалізації особистісно орієнтованого підходу до формування кроскультурної компетентності майбутніх фахівців галузі туризму, а також уможливлює розвивати та вдосконалювати мовленнєву діяльність [9]. Одним із різновидів цього методу є «конвертний» мозковий штурм. Мозковий штурм із використанням конвертів забезпечує чи не єдину форму індивідуального розв'язання учасниками окресленої проблеми. Такий метод добре спрацьовує наприкінці семінару. Тривалість його приблизно 30 хвилин.

Алгоритм проведення «конвертного» мозкового штурму

1. Розділіть учасників на групи (групи сідають навколо столів).

2. Роздайте кожному із членів групи конверт та листки паперу. У верхній частині конверта напишіть ключову фразу: “Проблема, яку я маю при спілкуванні з представниками інших культур за кордоном, полягає у ...”. Тема, яку повинні вибирати, звичайно стосується кроскультурної комунікації у майбутній професійній діяльності фахівця галузі туризму.

3. Дайте завдання учасникам, щоб вони закінчили речення чітким письмовим описом проблеми, яка хвилює студента. Вони повинні занотувати цей опис зверху на конверті. 
4. Після того, як усі описи буде занотовано, кожен учасник передає свій конверт сусідові. Тепер кожен із учасників має прочитати проблему, записану на конверті, взяти папір і написати на ній можливий варіант розв'язання проблеми.

5. Потім учасник вкладає картку в конверт і передає наступному учаснику. Він читає проблему і пише можливе її вирішення на новому аркуші паперу, не дивлячись на те, що вже було запропоновано.

6. Коли учасники врешті знову отримають свої конверти (пройшовши навколо усього столу), вони зачитують запропоновані шляхи вирішення проблем. Як завершальний етап, можна запропонувати студентам поділитися ідеєю, яку вони обрали для подальшого використання зі своєю групою (Інноваційна..., 2006).

«Модерація» (С. Маслова, 2001; В. Нікітін, Н. Суртаєва, 2015; I. Терешкіна та ін.,2008) - це метод групової роботи, спрямований на досягнення ефективного рівня ділової комунікації при демократичному плануванні та стимулюванні в умовах активної участі співробітників. Цей метод має такі характеристики: зосередження на конкретній проблемі; орієнтація не на конкуренцію, а на кооперацію; виключення формального контролю та оцінки діяльності студентів; містить способи діяльності, які вказують шлях розв'язання проблеми для групи; створення психологічно комфортних умов для суб'єктів професійної діяльності.

Наведемо приклад застосування методу модерації на тему «Що важливо для моєї культури?». Метою теми для обговорення є виявлення певних особливостей культури як середовища виховання; допомога студентам знайти подібності та відмінності представлених культур. Студентам (їх кількість - будь-яка, але оптимальна до 25 осіб) було запропоновано обговорити поняття культури в контексті кроскультурної освіти. Технічним засобом для обговорення можна обрати чат, наприклад, http://cross-cultural.chatovod.ru/ (pис. 1).
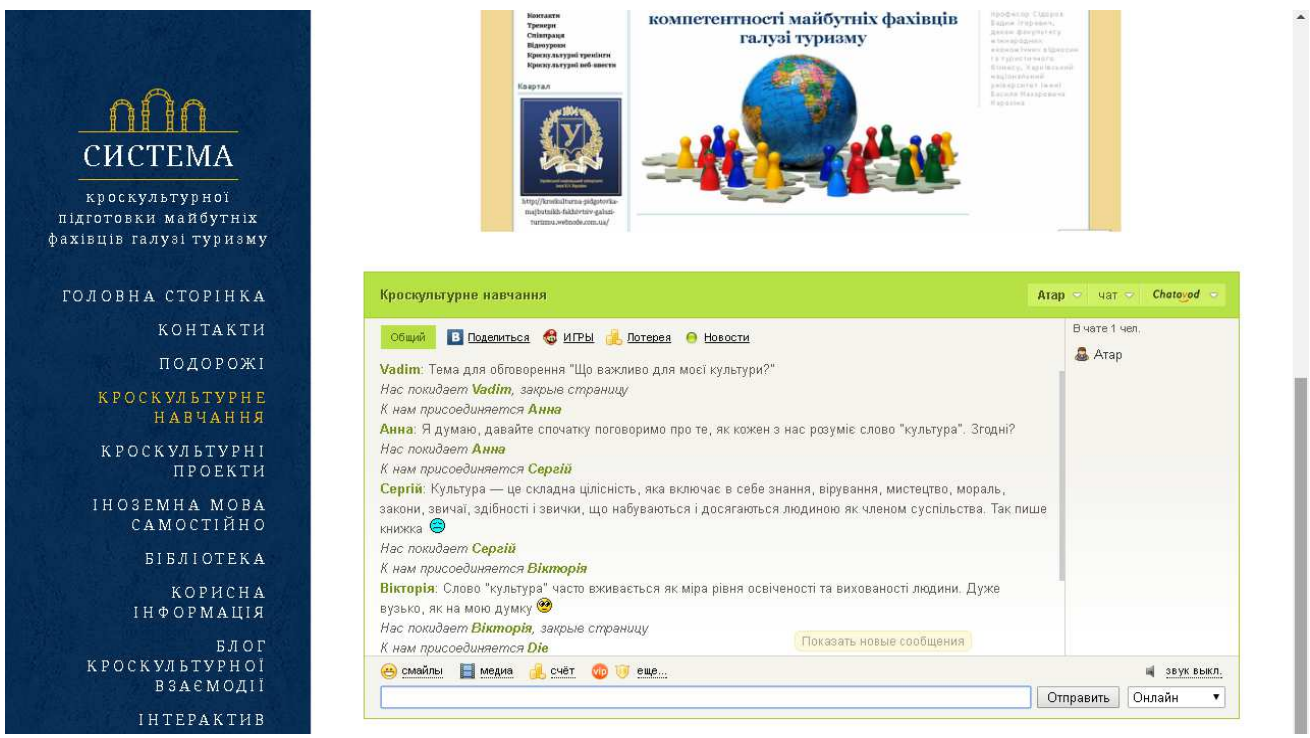

Рис. 1. Модерація в чаті

Студенти в чаті віддзеркалювали власний досвід, виходячи з позиції своєї сім'ї і культури, у якій виховувалися. Орієнтовно досвід відображався у руслі таких запитань: «У моїй родині діти повинні були...», «У моїй родині діти не повинні були ...», «Якщо в моїй родині дитина вередувала, то з нею ...», «У моїй родині пріоритетним завданням батьків є..», «Дитина проявляє повагу до старших шляхом...», «У моїй родині був прийнятий відпочинок ...», «У моїй родині працювали ...», «Найважливіші цінності нашої родини ...».

Запропоновані питання для всіх учасників після закінчення роботи в групі (чаті) носять загальний характер і не передбачають обов'язкової конкретизації. Після закінчення роботи викладач-модератор може прокоментувати поняття «культура» в контексті кроскультурної освіти.

Метод SWOT-аналізу (Strong, Weak, Opportunities, Threats - сильні, слабкі сторони, можливості, загрози) дає можливість всебічного аналізу явища, поняття, діяльності. Реалізує групову роботу студентів над аналізом певного об'єкту, наприклад, пам'ятки історії чи культури (рис. 2).

Наприклад, об'єкт - фонтан «Дзеркальний струмінь» (м. Харків). Студенти визначили: Strong (сильні сторони): старовинний, перебуває під захистом ЮНЕСКО, приваблює туристів; милує око, є одним із символів Харкова, є одним з найулюбленіших місць для зустрічей і відпочинку харків'ян; Weak (слабкі сторони): потребує реставрації та догляду, потребує коштів на утримання, відсутність стабільних джерел фінансування на утримання його в порядку, «клопіт» для місцевої влади; Opportunities (можливості): можливість «заробити» на туризмі, дає змогу науковцям дізнатися про минуле, сприяє формуванню громадянської позиції, можливості міжнародної співпраці; Threats (загрози): може зруйнуватися, зазнати шкоди від вандалів. 


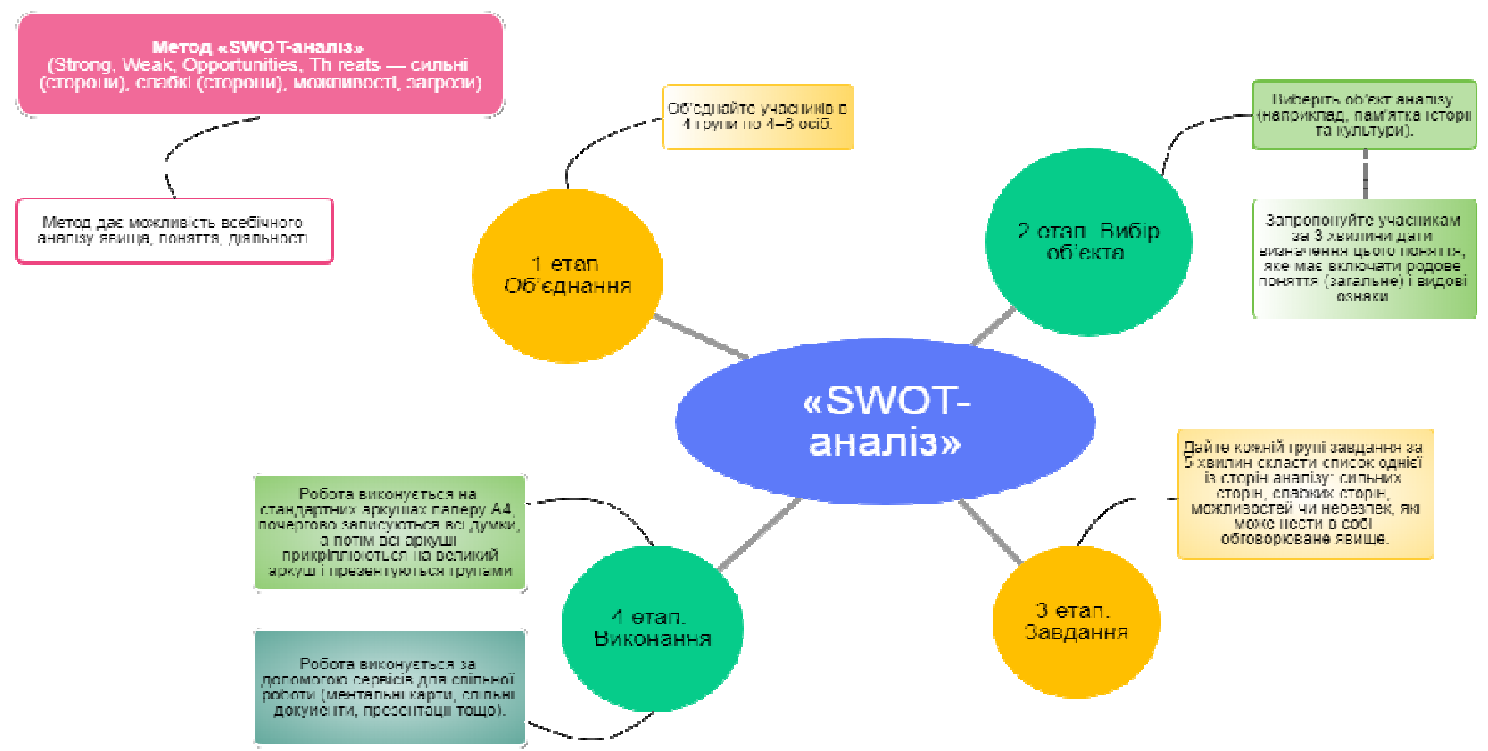

Рис. 2. Метод SWOT-аналізу

Викладачеві доцільно продовжити роботу, запропонувавши знайти шляхи уникнення несприятливих наслідків, перейти від аналізу до планування, а також продемонструвати, як за допомогою сильних сторін $\mathrm{i}$ можливостей можна здолати слабкі сторони та загрози (Спільна історія..., 2013).

Метод «Культурна капсула країни» $є$ різновидом методу проектів, основна цінність якого полягає у тому, що він орієнтує студентів на створення інформаційного продукту. Студенти у міні-групах за певний час повинні виконати пізнавальну, пошукову, дослідницьку, технологічну роботу на задану тему. Їхнє завдання отримати новий продукт, яким є сукупність “інфограм" культур різних регіонів світу та аналіз їх ціннісних вимірів. Прикладом інфограми може бути звичайна ментальна карта, створена у відповідних сервісах (напр., Mindmeister), яка може містити текст, графіку, відео (рис. 3).

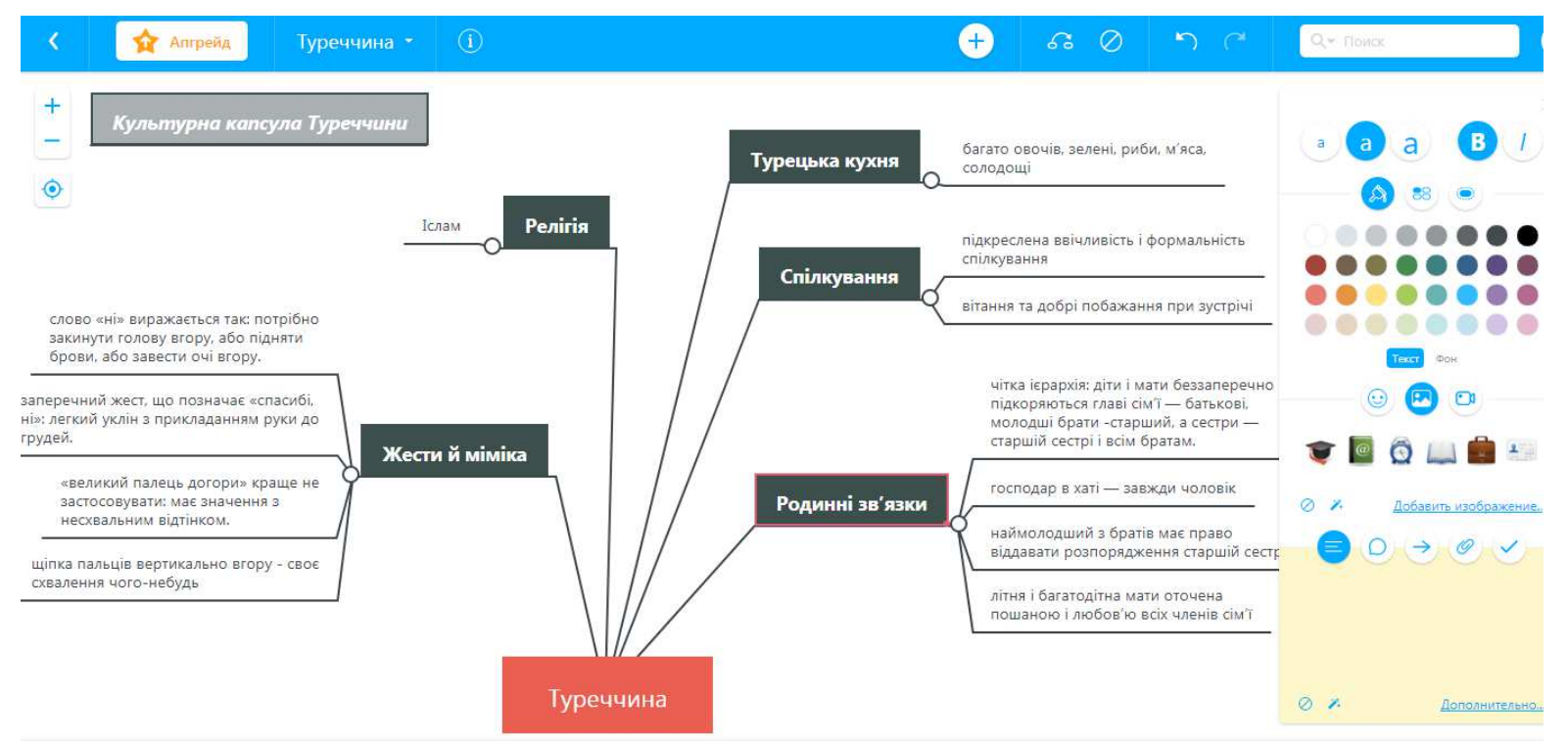

Рис. 3. Культурна капсула Туреччини

Суть цього методу можна визначити як "п'ять П+1": Проблема - Проектування (планування) - Пошук інформації - Продукт - Презентація + "шосте П" проекту - його Портфоліо, тобто папка, в якій зібрані всі матеріали проекту, у тому числі робочі матеріали, заготовки, знайдена текстова та графічна інформація тощо (Кононец, 2016). Інтегруючись з різними виконавськими функціями (автора проекту, координатора, адміністратора, виконавця), студенти практично опановують різні аспекти майбутньої професійної діяльності. Загалом, культурна капсула - це невеликий опис певних розбіжностей між українськими звичаями 
та звичаями інших культур, що супроводжується графічними об'єктами, що може бути представлена у вигляді інтерактивної презентації на 1-3 слайди з гіперпосиланнями (рис. 4).

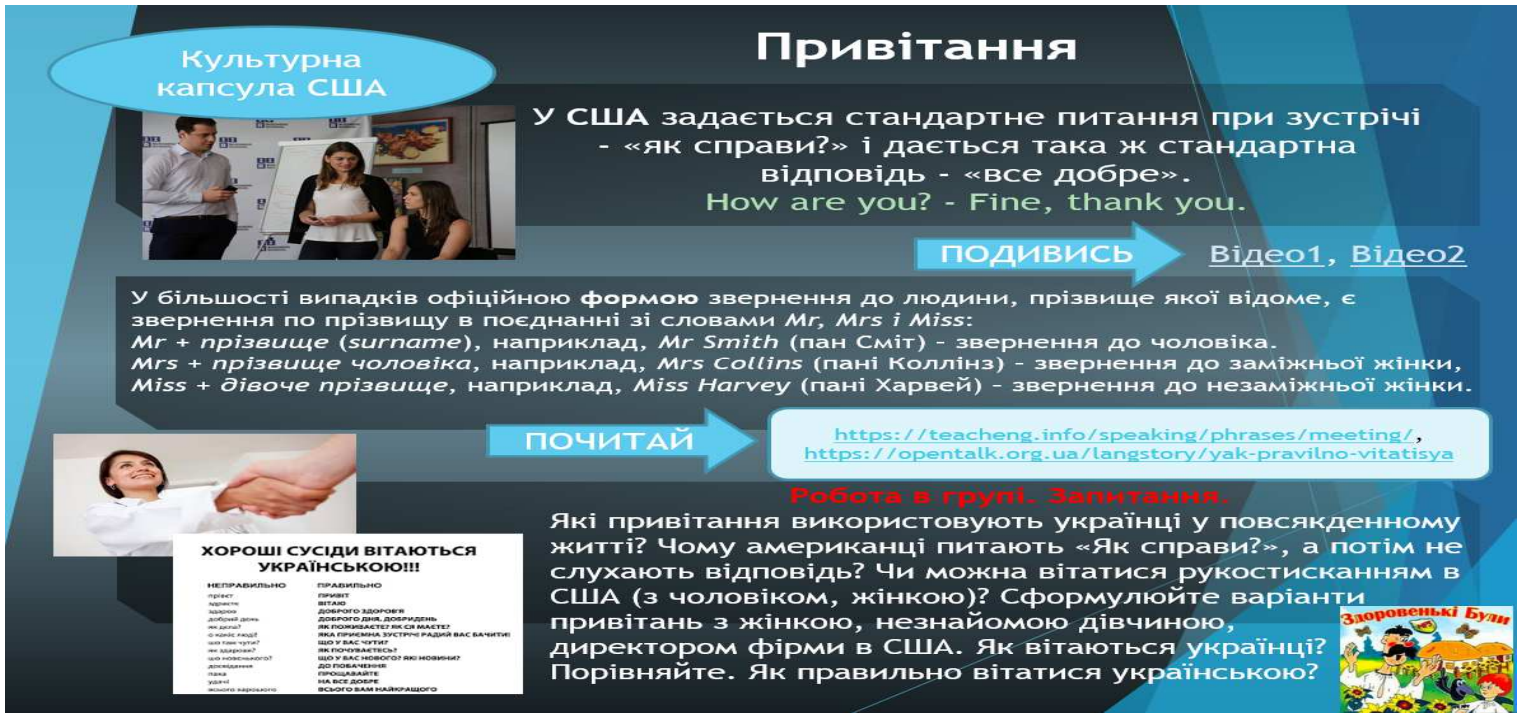

Рис. 4. Культурна капсула США (інтерактивна презентація)

Ключовою ідеєю цього методу є пошук відповіді на питання: "Які труднощі можуть виникнути у взаємодії з цими культурами у представників української культури?". Підсумком проекту мають бути підготовлені рекомендації для здійснення ефективної взаємодії з представниками різних культур. Крім того, особливістю виконання такого проекту може бути використання іноземної мови як інструменту отримання нових знань i вирішення поставлених завдань (Солодкая, Влияние..., 2014).

Слід зазначити, що використання Інтернет-ресурсів при розв'язуванні автентичних завдань мотивує студентів до вирішення проблем з неоднозначним рішенням, розвиваючи тим самим їх вміння пошуку кроскультурної інформації та перетворення ії в більш складне знання (розуміння). Це дозволить студентам досліджувати, обговорювати і усвідомлено будувати нові концепції і відносини в контексті реального світу, створювати проекти, що мають практичну значимість (Солодкая, Моделирование..., 2014).

Метод сторітеллінгу (Storytelling, «розповідання історій») нині тлумачиться як мистецтво захоплюючої розповіді. Цей досить новий метод у процесі формування кроскультурної компетентності майбутніх фахівців галузі туризму передбачає створення історії та передачі за її допомогою необхідної інформації 3 метою впливу на емоційну, мотиваційну, когнітивну сфери слухачів; розповідання смішних, зворушливих або повчальних історій з реальними або вигаданими персонажами. Історія має містити цікаву інформацію кроскультурного характеру, розповідати про конфлікти між представниками різних культур, зокрема, конфліктні ситуації, що виникають у галузі туризму в процесі організації та здійснення подорожей у контексті кроскультурного спілкування.

Так, студентам можна запропонувати скласти розповідь на тему «Моя туристична подорож». Мета - допомогти студентам усвідомити вплив різних чинників (країни проживання, релігії, культури, сім'ї тощо) на життя людини; сприяти появі інтересу і симпатії до культури інших людей; розвивати критичне ставлення до історії своєї країни; допомогти студентам краще пізнати один одного. Метод сторітеллінгу передбачає такі етапи:

Підготовка. Студентам слід визначитися з героєм історії, придумати йому ім'я, зовнішність, звички, риси характеру, як він буде діяти в тих обставинах, що ви створили для нього.

Початок. На цьому етапі студентові потрібно написати перший варіант історії.

Інтрига. Студент має придумати інтригу, пастку. Чим несподіванішим буде сюжетний поворот, тим краще.

Метафора. На цьому етапі студентові варто підібрати потрібні метафори (особливо для опису стану головного героя чи процесу, який описується). Записується оновлений варіант історії.

Корекція. Студент читає історію, вносить остаточні правки та корективи.

Оцінювання. Ключова ідея цього етапу: якщо ви оцінюєте історію, як нецікаву, робіть ці кроки стільки разів, скільки потрібно для «кристалізації» історії.

Так історії, написання яких може здійснюватися як рідною, так і іноземними мовами, мають бути націлені на підготовку студентів до життя і праці в умовах культури, що відрізняється від їх власної.

Метод «Вавілон» $є$ методом моделювання кроскультурної комунікації. Цей метод уможливлює розглянути аспект мовного розмаїття у процесі кроскультурної взаємодії, проаналізувати можливості невербальної 
комунікації. Він покликаний сприяти появі інтересу і симпатії до культури інших людей, допомогти розвитку у студентів комунікативних навичок. Реалізація цього методу відбувається за такими етапами:

1. Створення груп. Викладач розбиває студентів на кілька рівних груп. Кількість груп залежить від загального числа студентів. Наприклад, якщо всього 20 учасників, то утворюються 5 груп по 4 студенти.

2. Створення штучної мови. Групам пропонується упродовж 10 хвилин придумати свою мову, яка має відрізнятися від всіх відомих мов і не містити ніяких елементів 3 них. Мова повинна складатися 3 чотирьох слів: вітаю; до побачення; будь-який іменник (наприклад, сонце); будь-який прикметник (наприклад, яскравий). Отже, у кожної групи має з'явитися своя мова спілкування.

3. Спілкування. На цьому етапі викладач пропонує учасникам створити нові групи, в яких збереться по одному носію кожної з мов. 3 цього моменту студентам дозволяється розмовляти лише своєю новою мовою. Використання всіх інших мов або їх елементів неприпустимо, як і ведення записів. На цьому етапі перед кожним студентом стоїть завдання за 15-20 хвилин навчити нових партнерів своєї мови і, в свою чергу, «досконало» опанувати їх мови.

4. Обмін думками. Після закінчення відведеного часу студенти повертаються в свої початкові групи, де мають можливість обмінятися враженнями.

5. Аналіз. На цьому важливому етапі викладач разом зі студентами підводять підсумки, відповідаючи на серію запитань: Які емоції відчували студенти на різних етапах гри? (Придумуючи мову в початковій групі; навчаючи інших своєї мови; вивчаючи мову інших груп; повернувшись в «рідну» групу); Який з етапів гри був найбільш важким і чому? Які труднощі виникали у студентів у процесі гри? Чи вдалося всім студентам оволодіти мовами партнерів? Що допомагало виконати поставлене завдання? Чим ігрова ситуація нагадувала будь-які реальні життєві ситуації? Які висновки можна зробити, аналізуючи свій досвід участі в інтерактивній грі «Вавілон»?

Метод World Café («Всесвітнє кафе») полягає у зборі різних точок зору групи (як малої, так і великої) упродовж 1-2 годин відносно важливого питання або проблеми кроскультурного характеру. Перевагою цього методу є генерація учасниками великої кількості ідей, рішень, які відразу ж обговорюються, заперечуються або приймаються для подальшої роботи. У процесі обговорення концентрується кроскультурний досвід і значний об'єм знань присутніх, створюються умови для взаємного інтенсивного навчання. Основними учасниками цього методу $\epsilon$ «спонсор кафе» - особа, яка зацікавлена у проведені, «господар кафе» фасилітатор, «команда дизайну» - допомагає організовувати і проводити захід та є учасниками процесу реалізації методу.

Спочатку формуються групи по чотири студенти, призначається «господар столу». Перед кожною групою ставиться питання і обговорення триває 3-4 раунди, а потім студенти можуть перейти до інших столів. «Господарі» залишаються на своїх місцях, їх основне завдання - познайомити нових учасників з результатами роботи попередньої групи та фіксувати нові ідеї. Переміщення учасників відбувається до тих пір, поки кожен учасник повернеться за свій стіл. Тоді відбувається узагальнення ідей, створення галереї ідей і консолідація основних.

Етапи реалізації методу:

Представлення учасників дискусії (студентів), господарів і господинь столиків (викладачів, запрошених фахівців тощо) - 5 хв.

Ознайомлення із правилами проведення дискусії. Мультимедійна презентація проблеми - 15 хв.

Робота в групах - 20 хв.

Обмін столиками ( 1 -й перехід учасників) - 20 хв.

Обмін столиками ( 2-й перехід учасників) - 15 хв.

Презентація результатів кожного столу - 30 хв.

Підведення підсумків - 15 хв.

Загалом, The World Café дозволяє залучити до обговорення колективний інтелект учасників і закликає до багаторівневого діалогу, у процесі якого у студентів шліфується мистецтво розмови у відкритій атмосфері [Официальный сайт The World Cafe http://www.theworldcafe.com/; Принципы проведения The World Cafe).

Висновки. Усвідомлення викладацьким складом вищих навчальних закладів потреби сучасного кроскультурного суспільства в підготовці висококваліфікованих фахівців галузі туризму є важливим кроком до розробки авторських методичних систем формування у студентів спеціальності «Туризм» кроскультурної компетентності, що $€$ одним із вагомих резервів підвищення ефективності системи кроскультурної підготовки. Формування кроскультурної компетентності майбутніх фахівців галузі туризму буде успішним, якщо у процесі кроскультурного навчання студентів викладачі застосовуватимуть такі методи групової роботи як case-study, «мозковий штурм» (Brainstorming), модерація, SWOT-аналіз, «Культурна капсула країни», сторітеллінг (Storytelling), «Вавілон», World Café («Всесвітнє кафе»). Використання цих методів сприятиме розвитку в студентів здатності до кроскультурної комунікації в сфері майбутньої професійної діяльності, навичок кроскультурного спілкування, навичок і вмінь використовувати рідну та іноземну мову як засіб спілкування з представниками різних культур. Така система роботи зі студентами сприятиме створенню умов для засвоєння ними специфіки кроскультурних відносин, отримання інформації, доступної для представників іншої культури, використання всіх доступних засобів мовлення, подолання кроскультурних конфліктів (у разі виникнення проблеми учасники діалогу зможуть розширити або звузити межі конфлікту). 


\section{Список використаних джерел}

Бахтин М. М. Эстетика словесного творчества / М. М. Бахтин. -2-е изд.- М., 1986. - С. 429-432.

Інноваційна діяльність педагога: від теорії до успіху. Інформаційно-методичний збірник /Упоряд. Г.О. Сиротенко. Полтава: ПОІППО, 2006. - 124 с.

Кононец Н. В.Дидактичні основи ресурсно-орієнтованого навчання дисциплін комп'ютерного циклу студентів аграрних коледжів: дис. ... доктора пед. наук : 13.00.09 / Кононец Наталія Василівна. - Полтава, 2016. - 473 с.

Маслова С. Роль модератора фокус-групп: возможности и границы /С.Маслова // Практический маркетинг. - 2001. №9. - С. 10-14.

Методичний навігатор. Сторітеллінг. Взято 3: https://sites.google.com/a/lyceum2.cv.ua/metodicnij-navigator/metodicnimateriali/storitelling

Никитин В.Я. Модератор в системе фокус-группового исследования: учеб.-метод. пособие) / В.Я. Никитин, Н.Н. Суртаева. - СПБ. ИОВРАО, 2005. - 140 с.

Официальный сайт The World Cafe http://www.theworldcafe.com/

Принципы проведения The World Cafe Всемирного (интернационального) кафе. Адаптированный перевод М. А. Пронина и Р. Афтанделяна при участии Е.Марчук. Взято c: http://www.theworldcafe.com/wpcontent/uploads/2015/07/worldcafe-principles-rus.pdf

Сидоренко Л.М. Мозковий штурм як один з інноваційних методів в освітньому процесі студентів http://kumlk.kpi.ua/

Скрипник М. І. Інтерактивні технології в післядипломному навчанні: довідник / М. І. Скрипник ; НАПН України, ДЗВО «Ун-т менедж. освіти». - К., 2013. - 202 с.

Солодкая А.К. Влияние практики кросс-культурного взаимодействия / Science and Education a New Dimension. Pedagogy and Psychology, II(15), Issue: 30, 2014 http://seanewdim.com/

Солодкая А.К. Моделирование среды кросс-культурного взаимодействия в учебно-воспитательном процессе вуза / Тенденції розвитку вищої освіти в Україні: європейський вектор: Матеріали міжнародної науково-практичної конфере- нції, Ялта (220-21 березня 2014). Ялта: РЗВО КГУ, 2014. - Ч. 1. - С. 361-368.

Спільна історія. Діалог культур: Навчальний посібник. Видавництво Львів: ЗУКЦ, 2013, 256 ст

Технологии модерации в сфере социального взаимодействия: учеб.-метод. комплекс /И.Б. Терешкина, С.А.Векилова, Н.В.Солнцева, Н.Н.Суртаева - М, 2008. - 120 с.

Україна на світовому ринку туристичних послуг: сучасний стан та перспективи розвитку : монографія / [авт.-уклад. М. В. Сідоров, О. С. Юрченко, С. О. Юрченко.] - Х. : ХНУ імені В. Н. Каразіна, 2016. - 256 с.

\section{References}

Bakhtyn M. M. Эstetyka slovesnoho tvorchestva / M. M. Bakhtyn. -2-e yzd.- M., 1986. - S. 429-432.

Innovatsiina diialnist pedahoha: vid teorii do uspikhu. Informatsiino-metodychnyi zbirnyk/Uporiad. H.O. Syrotenko. Poltava: POIPPO, 2006. - 124 s.

Kononets N. V. Dydaktychni osnovy resursno-oriientovanoho navchannia dystsyplin kompiuternoho tsyklu studentiv ahrarnykh koledzhiv: dys. ... doktora ped. nauk : 13.00.09 / Kononets Nataliia Vasylivna. - Poltava, 2016. - $473 \mathrm{~s}$.

Maslova S. Rol moderatora fokus-hrupp: vozmozhnosty y hranytsы /S.Maslova // Praktycheskyi marketynh. - 2001. - №9. S. 10-14.

Metodychnyi navihator. Storitellinh. Vziato z: https://sites.google.com/a/lyceum2.cv.ua/metodicnij-navigator/metodicnimateriali/storitelling

Nykytyn V.Ia. Moderator v systeme fokus-hruppovoho yssledovanyia: ucheb.-metod. posobye) / V.Ia. Nykytyn, N.N. Surtaeva. - SPB. YOVRAO, 2005. - $140 \mathrm{~s}$.

Ofytsyalnыi sait The World Cafe http://www.theworldcafe.com/

Pryntsypы provedenyia The World Cafe Vsemyrnoho (ynternatsyonalnoho) kafe. Adaptyrovannыi perevod M. A. Pronyna y R. Aftandeliana pry uchastyy E.Marchuk. Vziato s: http://www.theworldcafe.com/wpcontent/uploads/2015/07/worldcafe-principles-rus.pdf

Sydorenko L.M. Mozkovyi shturm yak odyn z innovatsiinykh metodiv v osvitnomu protsesi studentiv http://kumlk.kpi.ua/

Skrypnyk M. I. Interaktyvni tekhnolohii v pisliadyplomnomu navchanni: dovidnyk/M. I. Skrypnyk ; NAPN Ukrainy, DVNZ «Un-t menedzh. osvity». - K., 2013. - 202 s.

Solodkaia A.K. Vlyianye praktyky kross-kulturnoho vzaymodeistvyia / Science and Education a New Dimension. Pedagogy and Psychology, II(15), Issue: 30, $2014 \mathrm{http}: / /$ seanewdim.com/

Solodkaia A.K. Modelyrovanye sredы kross-kulturnoho vzaymodeistvyia v uchebno-vospytatelnom protsesse vuza / Tendentsii rozvytku vyshchoi osvity v Ukraini: yevropeiskyi vektor: Materialy mizhnarodnoi naukovo-praktychnoi konfere- ntsii, Yalta (220-21 bereznia 2014). Yalta: RVNZ KHU, 2014. - Ch. 1. - S. 361-368.

Spilna istoriia. Dialoh kultur: Navchalnyi posibnyk. Vydavnytstvo Lviv: ZUKTs, 2013, 256 st

Tekhnolohyy moderatsyy v sfere sotsyalnoho vzaymodeistvyia: ucheb.-metod. kompleks /Y.B. Tereshkyna, S.A.Vekylova, N.V.Solntseva, N.N.Surtaeva - M, 2008. - 120 s.

Ukraina na svitovomu rynku turystychnykh posluh: suchasnyi stan ta perspektyvy rozvytku : monohrafiia / [avt.-uklad. M. V. Sidorov, O. Ye. Yurchenko, S. O. Yurchenko.] - Kh. : KhNU imeni V. N. Karazina, 2016. - 256 s. 


\title{
SIDOROV V.
}

Kharkiv National University named after VN Karazin, Ukraine

\section{SOME METHODS FOR FORMING CROSS-CULTURAL COMPETENCY OF FUTURE FACULTIES IN THE FIELD OF TOURISM}

The article describes the methods for forming the cross-cultural competence of future specialists in the field of tourism, namely: case study, Brainstorming, moderation, SWOT-analysis method, "Cultural Capsule of the Country", Storytelling, "Babylon", "The World Café". These methods are methods of group work with students. The process of cross-cultural training of students of the specialty "Tourism" involves the use of a set of these methods. An integrated combination of these methods will create an author's methodical system for the formation of cross-cultural competence of students. The use of these methods will promote the development of students' ability to cross-cultural communication in the area of future professional activities, skills of cross-cultural communication, skills and abilities to use native and foreign languages as a means of communication with representatives of different cultures. Such a system of work with students will help create the conditions for students to master the specifics of cross-cultural relations, obtain information available to representatives of another culture, the use of all available means of broadcasting, overcoming cross-cultural conflicts.

Key words: cross-cultural competence, tourism, specialist, cross-cultural training, method, group work

Стаття надійшла до редакції 12.04. 2018 р.

УДК 37.018.1:378.6:616-057.875:614.254.3:613

\section{ЄВГЕНІЯ СКРІННІК}

Вищий державний навчальний заклад України «Українська медична стоматологічна академія», м. Полтава

\section{ФАМІЛОГІЧНИЙ ПІДХІД У ФОРМУВАННІ ЦІННОСТЕЙ ЗДОРОВОГО СПОСОБУ ЖИТТЯ МАЙБУТНІХ СІМЕЙНИХ ЛІКАРІВ}

\begin{abstract}
Висвітлено значення фамілогічного підходу у процесі підготовки майбутніх сімейних лікарів до професійної діяльності. Визначено особливості формування цінностей здорового способу життя студентів-медиків. Розкритий зміст понять «фамілогія», «сімейні цінності», «цінність здоров’я особистості», «цінності здорового способу життя». Визначено мету і завдання фамілогічного підходу у формуванні цінностей здорового способу життя майбутніх сімейних лікарів.
\end{abstract}

Ключові слова: фамілогія, фамілогічний підхід, цінність здоров'я, цінності здорового способу життя, майбутні сімейні лікарі, навчально-виховний процес, професійна підготовка

На сучасному етапі реформування системи освіти в Україні, важливе місце посідає виховання патріотизму, звернення до самобутності українського народу, використання засобів української етнопедагогіки. Особливої уваги заслуговує професійна підготовка студентів-медиків, зокрема майбутніх сімейних лікарів. Сучасний сімейний лікар має стати достойним взірцем, своєрідним еталоном, власним прикладом втілювати принципи деонтології, превентивної медицини, основ здорового способу життя, фізичної рекреації та валеології, бути надійним помічником та порадником для своїх пацієнтів. Ураховуючи те, що сімейний лікар працює безпосередньо з родиною, вважаємо доцільним забезпечити вивчення студентами-медиками основ фамілогії та української етнопедагогіки в цілому.

Аналіз публікацій виявив, що проблеми реформування системи охорони здоров'я та професійної підготовки майбутніх сімейних лікарів розглядалась у роботах Т. Бахтеєвої (2010); О. Гиріної, В. Сірик, Н. Горобець та Т. Калюжної (2010); В. Лазоришинця, М. Банчука та В. Волосовець (2008); Б. Лемішко (2009); В. Лехана, Г. Слабкого та М. Шевченко (2009) та інших вітчизняних і зарубіжних дослідників. Але проблема використання сучасних педагогічних підходів, зокрема фамілогічного, у контексті дослідження вивчена недостатньо. 